\title{
Development of a Teacher Scale to Measure Presence and Frequency of Students' Resistance Behaviours
}

\author{
Mediha Sari \\ Faculty of Education, Cukurova University, Turkey
}

Copyright $\subseteq 2018$ by authors, all rights reserved. Authors agree that this article remains permanently open access under the terms of the Creative Commons Attribution License 4.0 International License

\begin{abstract}
Student resistance, which can briefly be defined as the tendency to resist teaching activities, is student's reacting to the teaching-learning activities, teachers, or administrators knowingly and wilfully, many times intentionally in various ways. Resistance behaviours, which could be considered as the outpouring of the anger created by the people or cases, have serious effects on the student's academic and social development. Therefore, it is important to struggle with them in an effective way. The first step of this struggle is surely identification of students' resistance behaviours. This study derives from the need for an instrument that can be used to measure students' resistance behaviours at school according to teachers' views. The study was conducted with 375 teachers from six primary schools and six secondary schools. Data were subjected to explanatory and confirmatory factor analysis, which created a 25 -item four-factor structure. These factors are "Resistance to Teacher Authority", "Hostile Attitudes towards the Teacher" "Continuous Anger", and "Passive Resistance". Analysis results indicate Student Resistance Behaviours Scale for Teachers (SRBS-T) is a reliable and valid tool to measure student resistance behaviours faced by teachers in their classrooms. While this tool could be used to identify student resistance behaviours encountered at schools according to teachers, other tools could also be developed to measure student resistance according to student views. Therefore, it is recommended to conduct studies that make statistical comparison of student and teacher views about resistance behaviours and to find solutions to the problems related to them.
\end{abstract}

Keywords Student Resistance, Resistance Behaviours, Scale Development

\section{Introduction}

One of the factors affecting students' academic and social development in education environments is resistance behaviours demonstrated by students occasionally. Resistance behaviours can generally be defined as the behaviours aimed at resisting teaching-learning behaviours knowingly and wilfully and even sometimes intentionally and sabotaging the flow of learning and teaching in the classroom. This concept typically refers to student behaviours and reactions when students are angry, disappointed, restrained, or isolated from the things going on in that environment [1]. To Yüksel [2], students react to cases that do not comply with their mentality, life styles, interests and expectations. When there is no change in these behaviours despite their reactions, students could turn these reactions into resistance.

Giroux, like Apple, Freire, Macedo, Willis, and McLaren is one of the pioneers of the "resistance" theory and concept [3]. According to Giroux [4], who states that the concept of resistance is theoretically and ideologically a very valuable structure for analysing the relationship between school and whole society, resistance has a meaning much beyond resisting an authoritative curriculum. Besides, understanding student resistance requires historical, political, cultural, economic and multiple point of views. To Giroux [4], schools are not merely teaching areas, and it is important to make a good and multidimensional analysis of school culture, which is affected by all dynamics [5]. According to Field and Olafsen [6], seeing student resistance as a struggle or anxiety is very important for a more holistic understanding. Such understanding helps us to see resistance as a phenomenon which is produced by the combination of the different factors related to each other.

By emphasizing that resistance behaviours are generally related to the individuals' experiences and attitudes and perceptions about these experiences, Miles [7] states that resistant students may demonstrate any or all of the following behaviours:

- Refuses to fulfil routine social or occupational tasks.

- Complains of being misunderstood or unappreciated.

- Is argumentative. 
- Is sullen.

- Criticizes or disrespects authority

- Expresses resentment towards others

- Displays verbal or physical defiance

- Is pessimistic

- Displays a negative attitude (p.11)

An analysis of these items stated by Miles might indicate that these behaviours are problematic behaviours frequently encountered in classroom environments. In fact, resistance behaviours should not be confused with the problematic behaviours students demonstrate in daily school life. While problematic behaviours are generally spontaneous reactions to various cases, resistance behaviours are purposeful reaction behaviours that are demonstrated knowingly, wilfully, and intentionally. As stated by Yüksel [2], to show a resistant behaviour, the students intentionally plan and repeat this behaviour continuously when it is convenient. For instance, if a student who reacts to his/her teacher about something does not raise hand to answer the question even if $\mathrm{s} /$ he knows the answer and avoids communicating with the teacher, this should be considered as resistance behaviour. It is highly important to distinguish resistance behaviours from problematic behaviours so that they can be solved. These kinds of behaviours are students' logical reactions; students might be experiencing feelings of anger and revenge because they think that they are hard done by, isolated, neglected, humiliated, and subject to discrimination; their educational needs are not met; and they find the curriculum and /or other teaching practices boring. Resistance behaviours could be demonstrated as an expression of these feelings.

Field and Olafsen [6] report that majority of teachers viewed almost all resistant behaviours demonstrated by students as negative. However, not all resistance behaviours should be perceived negative. There are some studies which classify these behaviours as constructive and destructive resistance behaviours. For instance, Seidel and Tanner [1] state that behaviours against teachers could be addressed as constructive or destructive student behaviours; and constructive resistance behaviours include asking challenging questions, suggesting revisions, helping other students without asking the teacher, and making suggestions to the teacher about his/her development. In other words, behaviours such as asking meaningful questions and questions that ask about the process, working on projects without approval of the teacher, making explanations and revisions about the course materials, and objecting teachers' inappropriate teaching activities and ideas are considered constructive and positive resistance behaviours as they improve and deepen learning [8]). Zhang [9], stating that teachers generally do not like resistance behaviours, emphasizes that student resistance could chance classroom environment dramatically, and even fully disrupt and prevent the lesson.
As it is seen in the studies in the literature, whether it is perceived positive or negative, student resistance behaviours could affect the quality of learning process dramatically. Particularly destructive resistance behaviours might cause serious problems in the learning process not only for students themselves and their friends but also for teachers. Presence of students who constantly resist learning and reject teachers' instruction could decrease the teacher's motivation and job satisfaction, which might affect productivity in a negative way. While Ruggeri-DiLello [10] reported results which indicated the effects of students' resistance behaviours on teacher self-efficacy, Hastings and Bham [11] found that student behaviours significantly predicted teacher burnout. In fact, as stated by Beşdok [12], if the teacher does not enjoy his/her work or feel excited about it, teaching becomes a problematic occupation. Besides, if the teaching process is not made enjoyable both for the teacher and the student, behaviours that might emerge include resistance, low motivation, short attention span, indifference, even anger and getting rid of the system as soon as possible. From this point of view, there seems to be a mutual relationship between teacher motivation and student resistance behaviours. While a cheerful, happy and self-confident teacher creates a positive learning environment by increasing motivation, opposite cases yield negative outcomes [17]. Despite the importance it has, resistance behaviours encountered by teachers seems to be one of the topics neglected in the field. On the other hand, review of the literature indicates that there are no measurement tools available for identifying the existence and frequency of resistance behaviours at schools. This study was designed to meet the need and effort of a measurement tool to identify the existence and frequency of resistance behaviours according to teachers' views.

\section{Method}

\subsection{Research Design}

This study attempts to develop a measurement tool which identifies the existence and frequency of primary and secondary school student resistance behaviours at schools from teachers' views.

\subsection{Target Population and the Participants}

Target population of the study was the teachers who worked in primary and secondary schools in the central towns of Adana in the 2016-2017 education year. Six primary and six secondary schools were identified from typical state schools in this target population, using random cluster sampling method. The participants were 375 teachers who worked in these schools and volunteered to 
participate in the study. Of all the teachers, 183 were primary school teachers, 192 were secondary teachers, 205 were female, and 168 were male. Explanatory factor analysis (EFA) was conducted with the data obtained from 190 teachers. Of these teachers, 117 were primary school teachers, 73 were secondary school teachers; 97 were female, and 93 were male. Confirmatory factor analysis (CFA) for the Student Resistance Behaviours Scale for Teachers (SRBS-T) was performed with data collected from a different sample of 185 teachers. 66 of these teachers in this sample were primary school teachers, 199 were secondary school teachers, 108 were female, and 75 were male.

\subsection{Preparation Process for the Student Resistance Behaviours Scale for Teachers (SRBS-T)}

Steps to be followed for a scale development were explained in various sources [14-17]. According to the explanations in these references, development of SRBS started with the literature review and clarification and definition of the concepts. First of all, resistance theory and student resistance definition, and theoretical explanations about these concepts were examined; information was obtained about the definition, features, sources and coping strategies about student resistance behaviours. Following this step, a pool was formed with 63 draft items. This item pool was prepared for expert opinions, and it was examined by six instructors working at Çukurova University Education Faculty Educational Sciences Department and five teachers. Some items were revised in line with their views; five items were totally excluded, and two items were added. As a result of these procedures, the 60-item trial form was tested in terms of language and expression by administering it to 20 teachers, 10 primary school teachers, and 10 secondary school teachers. At the end of this testing, there was no need to exclude any items; only the statements in some items were revised. Data were collected through this 60 -item revised scale administered to 375 teachers from 12 schools. These 375 teachers were randomly divided into two groups. The data obtained from 190 teachers were subjected to explanatory factor analysis, and the data obtained from 185 teachers were used for confirmatory factor analysis.

\subsection{Analysis of the Data}

For reliability and validity purposes, Cronbach's alpha analysis was performed for reliability; expert opinions were analysed for content validity; and explanatory and confirmatory analysis (EFA and CFA) was performed for construct validity. Besides, arithmetic mean scores and standard deviation values and item-total correlations were analysed.

\section{Findings}

\subsection{Findings Obtained from Explanatory Factor Analysis and Reliability Analyses}

Kaiser-Meyer-Olkin (KMO) coefficient and Barlett Sphericity test results were analysed in order to find out if the data given at the beginning of factor analyses were appropriate for analysis; these values were found to be statistically significant $(\mathrm{KMO}=0.93$; Barlett Sphericity test $\left.\chi^{2}=3705.317, \mathrm{df}=406, \mathrm{p}<.001\right)$. In addition, skewness and kurtosis coefficients, item-total correlations, communalities, factor loads (min. 40) and differences between the factors loaded to more than one factor (min .20) were analysed. As a result, it was decided that 31 items should be excluded from the scale. These procedures were performed using principal components factor exclusion analysis and orthogonal (varimax) rotation.

Criteria to be used for the identification of the number of total factor include Eigen value, contribution rate to total variance, and scree plot [14-20]. Beside these, having significant and sufficient number of appropriate items could be another criterion. First analysis results showed that the scale included 7 factors that had Eigen value of over 1.00. However, an analysis of the items that were loaded below the factors showed that the last two dimensions had one item in each; and the items in one dimension were loaded above .30 under other factors, too; the loads under two factors were close to each other. Besides, variance rates explained by the last three factors were found to decrease significantly. An analysis of the scree plot obtained in this analysis indicated a significant decline between the third and fifth factors. Büyüköztürk [18] reports that the factor that has high acceleration with low decline in scree plot gives the number of important factor. In this regard, analyses continued after the factor number was decided to be four.

Figure 1 demonstrates the scree plot analysed in these analyses.

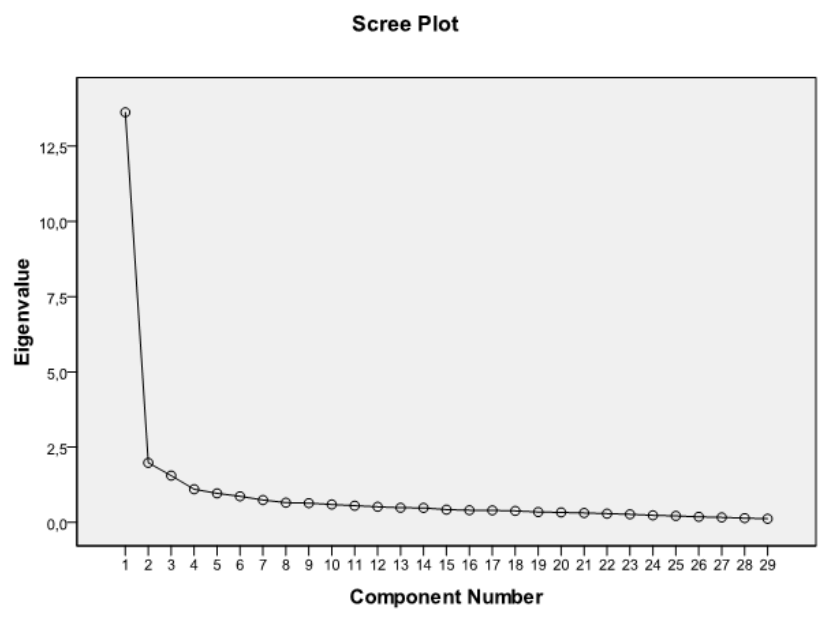

Figure 1. Scree Plot obtained in EFA 
The factor analysis resulted in a four factor structure with 29 items reached in six iterations. Table 1 demonstrates factors, factor loads, factor eigenvalues, variance ratios explained by factors and Cronbach's Alpha internal consistency coefficients in explanatory factor analysis and reliability analyses conducted in the study, revised item-total score correlations (r), communalities and arithmetic mean, and standard deviation values of the items.

As it is seen in Table 1, the first factor obtained from the explanatory factor analysis is "Resistance to Teacher Authority", which expresses students' disobedience to the teacher's authority. This factor involves 11 items such as "some students in my school / class do not tolerate being under control, they act as if they are constantly trying to discourage the teacher; they consciously do not bring the necessary materials needed in the class. Factor loads of these items are between .58 and .76; Item-total score correlations are between .64 and .77; and Cronbach's Alpha internal consistency coefficient is .93.

The second factor of the SRBS is "Hostile Attitudes towards the Teacher" dimension which has 9 items such as "Some students in my school / class show with their behaviours that they do not like their teachers, they constantly criticize the teacher's instruction". Factor loads of the items listed here are between .56- and 76; Item-total score correlations are between .52 and .75 . Cronbach's alpha internal consistency coefficient of this factor is .90 .

"Continuous anger" is the third factor of SRBS, and it consists of four items such as "Some students in my school/class are always straight-faced, they are always ready for arguments and fights". Factor loads range between .62 and .75 , and item-total correlations are between .61 and .78. Cronbach's alpha internal consistency coefficient is .86 .

Table 1. EFA and reliability analysis results conducted for SRBS-T

\begin{tabular}{|c|c|c|c|c|c|c|c|c|c|}
\hline Old No & New No & F1 & $\mathrm{F} 2$ & F3 & F4 & $\mathrm{r}$ & Communality & Mean & $\mathrm{Sd}$ \\
\hline 36 & 1 & .76 & & & & .74 & .71 & 2.65 & 1.12 \\
\hline $56^{*}$ & 2 & .72 & & & & .72 & .66 & 2.37 & 1.04 \\
\hline 35 & 3 & .71 & & & & .64 & .59 & 2.68 & 1.17 \\
\hline 38 & 4 & .71 & & & & .77 & .66 & 2.28 & 1.08 \\
\hline $57 *$ & 5 & .66 & .398 & & & .76 & .71 & 2.21 & 1.02 \\
\hline 37 & 6 & .64 & & & & .75 & .64 & 2.24 & 1.05 \\
\hline $39^{*}$ & 7 & .63 & .384 & .384 & & .77 & .70 & 2.18 & 1.01 \\
\hline 58 & 8 & .63 & .426 & & & .75 & .66 & 2.15 & .98 \\
\hline 34 & 9 & .63 & .377 & & & .72 & .60 & 1.84 & .88 \\
\hline 52 & 10 & .61 & & .351 & & .73 & .60 & 2.27 & 1.06 \\
\hline 44 & 11 & .58 & & .363 & & .73 & .62 & 2.11 & .99 \\
\hline $23^{*}$ & 12 & & .761 & & & .66 & .63 & 1.45 & .74 \\
\hline 32 & 13 & .356 & .661 & & & .71 & .62 & 1.60 & .76 \\
\hline 10 & 14 & & .659 & & & .52 & .53 & 1.41 & .74 \\
\hline 60 & 15 & .377 & .654 & & & .75 & .65 & 1.74 & .88 \\
\hline 55 & 16 & .395 & .652 & & & .67 & .59 & 1.96 & .90 \\
\hline 41 & 17 & & .643 & .354 & & .72 & .63 & 1.72 & .88 \\
\hline 22 & 18 & & .624 & & & .68 & .56 & 1.75 & .88 \\
\hline 50 & 19 & & .619 & & & .68 & .56 & 1.64 & .80 \\
\hline 18 & 20 & & .562 & & & .61 & .47 & 1.78 & .89 \\
\hline 27 & 21 & & & .756 & & .70 & .72 & 2.06 & .95 \\
\hline 29 & 22 & & .352 & .712 & & .78 & .76 & 2.10 & .97 \\
\hline 28 & 23 & & .415 & .656 & & .75 & .72 & 2.01 & .86 \\
\hline 26 & 24 & .353 & & .623 & & .61 & .60 & 2.40 & 1.00 \\
\hline 2 & 25 & & & & .762 & .46 & .60 & 2.57 & .89 \\
\hline 1 & 26 & & & & .631 & .59 & .55 & 2.39 & .93 \\
\hline 3 & 27 & & & & .630 & .43 & .47 & 2.32 & .87 \\
\hline 11 & 28 & .498 & & & .607 & .69 & .69 & 2.47 & 1.00 \\
\hline 12 & 29 & .417 & & & .528 & .63 & .61 & 2.31 & 1.08 \\
\hline \multicolumn{2}{|c|}{ Eigenvalue } & 13.62 & 1.98 & 1.55 & 1.10 & \multicolumn{4}{|c|}{ Total } \\
\hline \multicolumn{2}{|c|}{ Variance \% } & 46.98 & 6.83 & 5.36 & 3.80 & \multicolumn{4}{|c|}{62.97} \\
\hline \multicolumn{2}{|c|}{ Cronbach's Alpha } & .93 & .90 & .86 & .78 & \multicolumn{4}{|c|}{.95} \\
\hline
\end{tabular}

*These items needed to be excluded from the scale as a result of CFA

r: Item-total correlations

Note: Factor loads less than .30 are not shown on the table for readability

F1: Resistance to Teacher Authority; F2: Hostile Attitudes towards the Teacher; F3: Continuous Anger; F4: Passive Resistance 
The fourth factor of the SRBS is the "Passive Resistance" dimension which includes behaviours such as students' putting distance between their teachers, keeping communication channels closed, and do not care about what is going on in the class. This 5-item factor includes items such as "Some students in my school / class do not want to raise their hand although they know the answer; they knowingly try to avoid the teacher's notice". Factor loads of these five items are between .52 and.76; Item-total correlations are between .46 and .69; and Cronbach's alpha internal consistency coefficient is .78 .

Four subscales obtained from the factor analysis explain $62.97 \%$ of the total variance. Cronbach's Alpha internal consistency coefficient for the total scale is .95 . Guttmann Split Half values were also examined to analyse the stability of the scale or the stability between the two halves. Accordingly, Guttmann split half values were .92 for the first factor, .89 for the second factor, .86 for the third factor, .77 for the fourth factor, and.91 for the whole scale.

The arithmetic mean of the remaining 29 items range between 1.45 and 2.68 , and the standard deviations range between .74 and 1.17. An analysis of Table 2 in terms of factor loads indicate that all items have a factor load of over .50, and that they were loaded significantly under the relevant factors. However, items 11 and 12 under the fourth factor do not meet the rule of "there should be at least 20 differences between the loads under two factors", they were found to load above .40 in the first factor. However, an analysis of the expressions of these two items shows that they are composed of the items "they try to avoid the teachers notice knowingly" and "although they want to learn the topic, they prefer to sit at the back of the class and / or not to attend the lesson"; both items should be under the "Passive Resistance" factor in terms of meaning. Moreover, both items under this factor were loaded.50. On the other hand, there are also some sources indicating that it is sufficient if the difference between the loads under two factors is at least .10 [14,19-20]. In addition, when these two items were excluded from the "passive resistance" factor in the reliability tests, the Cronbach's alpha coefficient of .78 was found to decrease to .59 . As a result of all these analyses, it was decided that these two items should remain in the scale and be included in the "passive resistance" subscale.

Table 3 demonstrates correlation matrix and associated arithmetic mean and standard deviation values in relation to Student Resistance Behaviours Scale (SRBS) total scores and subscales.

Table 2. Criteria for Goodness-of- fit Indices and Fit Indices obtained in the Study

\begin{tabular}{|c|c|c|c|}
\hline Fit Measure & Good fit & Acceptable fit & Values obtained \\
\hline $\mathrm{X} 2 / \mathrm{sd}$ & $0 \leq \mathrm{X} 2 / \mathrm{df} \leq 2$ & $2 \leq \mathrm{X} 2 / \mathrm{df} \leq 3$ & 1.50 \\
\hline$P$ value & $.05<\mathrm{p} \leq 1$ & $.01 \leq \mathrm{p} \leq .05$ & .00 \\
\hline RMSEA (Root Mean Square Error of Approximation) & $0 \leq \mathrm{RMSEA} \leq .05$ & $.05 \leq$ RMSEA $\leq .08$ & .052 \\
\hline NFI (Normed Fit Index) & $.95 \leq \mathrm{NFI} \leq 1.00$ & $.90 \leq \mathrm{NFI} \leq .95$ & .97 \\
\hline NNFI (Non-Normed Fit Index) & $.97 \leq \mathrm{NNFI} \leq 1.00$ & $.95 \leq \mathrm{NNFI} \leq .97$ & .99 \\
\hline SRMR (Standardized Root Mean Square Residual) & $0 \leq \mathrm{SRMR} \leq .05$ & $.05 \leq \mathrm{SRMR} \leq .10$ & .046 \\
\hline GFI (Goodness of Fit Index) & $.95 \leq \mathrm{GFI} \leq 1.00$ & $.90 \leq \mathrm{GFI} \leq .95$ & .85 \\
\hline AGFI (Adjusted Goodness of Fit Index) & $.90 \leq \mathrm{AGFI} \leq 1.00$ & $.85 \leq \mathrm{AGFI} \leq .90$ & .82 \\
\hline CFI (Comparative Fit Index) & $.97 \leq \mathrm{CFI} \leq 1.00$ & $.95 \leq \mathrm{CFI} \leq .97$ & .99 \\
\hline
\end{tabular}

Schermelleh-Engel \& Moosbrugger, [25].

Table 3. Correlation matrix, arithmetic mean and standard deviation values in relation to Student Resistance Behaviours Scale (SRBS) total scores and subscales.

\begin{tabular}{|l|c|c|c|c|c|c|}
\hline & 1 & 2 & 3 & 4 & Mean & Sd \\
\hline 1. Resistance to Teacher Autonomy & - & & & & 2.27 & .82 \\
\hline 2. Hostile Attitudes towards the Teacher & $.73^{* *}$ & - & & & 1.67 & .62 \\
\hline 3. Continuous Anger & $.72^{* *}$ & $.69^{* *}$ & - & & 2.14 & .80 \\
\hline 4. Passive Resistance & $.64 * *$ & $.55^{* *}$ & $.50^{* *}$ & - & 2.41 & .70 \\
\hline 5. SRBS Total Scores & $.94^{* *}$ & $.87^{* *}$ & $.82^{* *}$ & $.74 * *$ & 2.09 & .64 \\
\hline
\end{tabular}

$\mathrm{N}=190,{ }^{* *} \mathrm{p}<0.01$ 
As it is shown in Table 3, the four subscales of SRBS-T showed significant relationships with each other and with the total score $(p<0.01)$. Significant relationships were noted for Resistance to Teacher Authority subscale .73, .72 and .64 respectively with other subscales and.94 with total score; Hostile Attitudes towards the Teacher .69 with Continuous Anger subscale; .55 with Passive Resistance subscale, and .87 with total scores; Passive resistance subscale .50 with Continuous Anger subscale and .82 with total scores. The arithmetic mean values of subscales and total scores of the scale were between 1.67 and 2.41; standard deviations range from .62 to .82 .

\subsection{Findings Obtained from Confirmatory Factor Analysis}

After the exploratory factor analyses were completed, confirmatory factor analyses were performed on the data collected from a different sample of 185 teachers.
In this analysis process, Item number 2 (former no:56), 5 (former no:57), 7 (former no:39) and 12 (former no: 23) needed to be excluded from the scale; and the 25-item model which included the same factors was found to have the best fit indices values $\left(\chi^{2}=405.04, \mathrm{df}=269, \mathrm{p}=.000, \chi^{2}\right.$ $/ \mathrm{sd}=1.50)$.

Table 2 demonstrates comparative analysis of fit indices obtained as a result of CFA with values taken as criteria.

An analysis of goodness indices for SRBS-T in Table 2 shows that the criteria indicated in the literature [20, 25-27] were generally met. However, the GFI value, which is recommended to be at least .90 , was .85 and AGFI valuewhich is recommended to be at least .85 , was .82 . As these values are quite close to the acceptable values and as almost all the other fit indices indicated perfect fit, these two values were accepted, indicating that the scale has a good fit. Figure 2 demonstrates the path diagram in relation to this model.

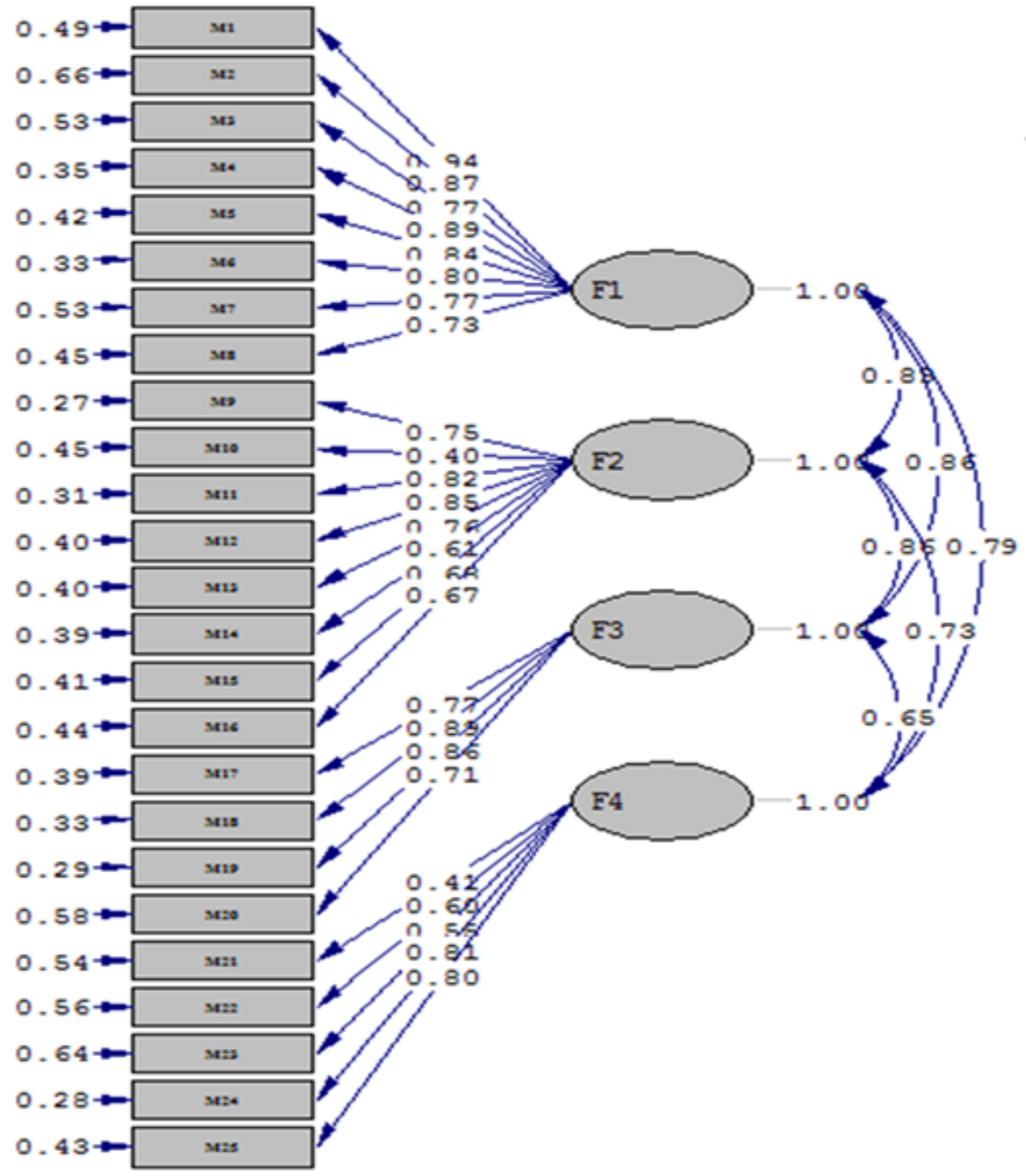

Chi-Square $=405.04, \mathrm{df}=269, \mathrm{p}$-value $=0.00, \mathrm{RMSEA}=0.052$

Figure 2. Path diagram of the CFA solution for SRBS-T 
After the confirmatory factor analysis was completed, reliability analysis was renewed for the 25 -item structure of the four-factor scale. According to this analysis, while Cronbach's alpha internal consistency coefficient for the whole scale was .95 , it was .91 for the eight-item "Resistance to Teacher Authority" subscale; .89 for the eight-item "Hostile Attitudes towards the Teacher" subscale, .85 for the four-item "Continuous Anger" subscale, and .79 for the five-item "Passive Resistance" subscale.

Responding and Scoring Student Resistance Behaviours Scale for Teachers (SRBS-T)

SRBS-T is a 5 point Likert type (1. Never; 2. Rarely; 3. Sometimes; 4. Very Often; 5. Always) tool for teachers which can be used for the identification of the existence and frequency of primary and secondary school students' resistance behaviours according to teachers' views. Each of the 25 items in the scale is related to different resistance behaviour, and the teachers were asked to identify the frequency of observing these behaviours at their school. A Sample about teachers' responses is as follows:

\begin{tabular}{|c|l|l|l|l|l|}
\hline Some students in my school / class; & 1. Never & 2. Rarely & 3. Sometimes & 4. Very Often & 5. Always \\
\hline Do not tolerate being under control & & & & & \\
\hline Act as if they are constantly trying to discourage the teacher & & & & & \\
\hline
\end{tabular}

No conversion is required for the items. Higher scores indicate more frequently encountered resistance behaviours in school environments. Scores to be obtained from SRBS-T range between 25 and 125 . Scoring based on the subscales indicates that scores range between 8 and 40 in the 8-item "Resistance to Teacher Authority" and "Hostile Attitudes towards the Teacher" subscales, between 4 and 40 in the 4-item "Continuous Anger" subscale, and between 5 and 25 in the 5-item "Passive Resistance" subscale. However, to make it easier to interpret, each scale score can be converted into 1 to 5 scale by dividing it by the number of items covered.

\section{Discussion, Conclusion and Recommendations}

This study attempts to develop a scale which could be used to identify existence and frequency of resistance behaviours demonstrated by primary and secondary school students in the education environments. A 4-factor, 25 -item tool was obtained from the analyses. The factors in the Student Resistance Behaviours Scale included "Resistance to Teacher Autonomy", "Hostile Attitudes towards the Teacher", "Continuous Anger" and "Passive Resistance". These factors are parallel to the resistance behaviour types explained in the studies about student resistance behaviours $[7,8,28]$. The values in the validity and reliability studies of the SRBS-T indicate strong evidence that the scale is appropriate to use. The high total variance value explained in the scales indicates that the concept or structure is well-measured [23]. Sheskin [29] states that factors obtained from this concept show how much it can explain the change in the data. While some researchers indicate that they are looking for at least $70 \%$ of the explained variance, there are no certain rules as to how much of the total variance should be explained. The four factors in SRBS-T explain $62.97 \%$ of the total variance. As stated by Sheskin [29], although there are some researchers who claim that the total explained variance should be over $70 \%$, there are also some explanations indicating that over $30 \%$ is generally acceptable for Social Studies. For instance, Tavşancıl [16] states that rates between $40 \%$ and $60 \%$ could be accepted as sufficient for Social Studies. Büyüköztürk [23] states that $30 \%$ is considered adequate for one-factor scales in behavioural sciences, but higher ratios are expected for multi-factor scales. In this case, the ratio of variance explained by the SRBS-T is adequate. Thus, this tool is considered to measure the students' resistance behaviours at a satisfactory level.

Factor analysis results showed that the factor loads of all items in four factors were higher than .50. Factor load values indicate the correlation between the variable (item) and factor; and these values are expected to be high. Load values between .30 and .59 are considered to be at moderate level, load values above .60 are considered to be high [20].

An analysis of the explanations in the literature shows that factor loads over .30 are accepted to be adequate [16, 29-30]. All but three factors in SRBS-T were found to be loaded over .60; in other words, the items had strong relationships with the factor they belonged to.

As a result of reliability analysis for SRBS-T, Cronbach's Alpha internal consistency coefficients were found to be between .78 and .93 for the subscales and .95 for the scale total scores. In addition, confirmatory factor analysis was repeated on the data collected from a different sample for confirmatory factor analysis, and the Cronbach's alpha internal consistency coefficient was .95 for the total scale, and ranged between .79 and .91 for the four subscales. These values are above .70 , which is indicated adequate in literature [14-19, 31-32]. Based on this evidence, SRBS-T is considered to be a highly reliable 
tool with high internal consistency. Another indicator of high internal consistency is the high item-total score correlations belonging to the items. Only two out of 25 items in the scale were found to have a total correlation below .50. Büyüköztürk [23] states that items with correlations over .30 have higher distinguishing power. Based on this, all the items in SRBS-T are considered to be appropriate both in terms of distinguishing features and in terms of internal consistency. In conclusion, values obtained from the reliability and validity analyses show that SRBS-T is a valid and reliable tool that can be used in similar studies.

Following recommendations have been made in line with the explanations above;

- Although statistical analyses show that SRBS-T is an appropriate tool to use, it has an important limitation; presence of resistance behaviours, which have internal and subjective features, is assessed by teachers rather than students themselves. Resistance behaviours, the outpouring of internal negative feelings against any component of students' learning process (mainly teacher or education program), are many times planned beforehand and demonstrated. Observable parts of these behaviours by teachers are limited. Therefore, it is recommended that SRBS-T, which is prepared for teachers, should be adapted to students' level.

- Quantitative data collection methods have an important advantage; they enable to obtain generalizable data from large groups. However, in depth and quantitative measurement of resistance behaviours which have highly intensive nature in terms of their intrinsic aspect as well does not seem to be possible by simply applying a questionnaire or scale. For this reason, when using a measurement instrument such as SRBS-T, due to its nature of the issue, the nature of resistance behaviours could be explored in depth and in a more detailed way by gathering qualitative data.

- The SRBS-T developed in this study is for primary and secondary school levels. Considering that each level might demonstrate different resistance behaviours, different scale versions could be developed for primary, secondary, high school, and university levels.

- $\quad$ This study aims to develop a tool. Therefore, only validity and reliability findings are accessed, and it was considered to be adequate. SRBS-T could be used as a data collection tool in other studies, and student resistance behaviours could be investigated in large groups.

- Other variables which might be associated with resistance behaviours in other studies could also be included in the studies, and sources of these behaviours and coping strategies could be investigated together.

\section{REFERENCES}

[1] Seidel, S. B., \& Tanner, K. D. (2013). What if students revolt?-Considering Student Resistance: Origins, Options, and Opportunities for Investigation. CBE-Life Sciences Education, 12, 586-595.

[2] Yüksel, S. (2004). Eğitim fakültesi öğrencilerinin öğretme-öğrenme süreçlerine yönelik direnç davranışları [resistance behaviors of education faculty students to teaching and learning process]. Türk Eğitim Bilimleri Degisi, 2(3), 323-340.

[3] Margolis, M. (2001). The Hidden Curriculum in Higher Education. New York: Routledge Falmer.

[4] Giroux, A. H. (1983). Theory and Resistance in Education: A Pedagogy for the Opposition. Massachusetts: Bergin \& Garvey Publishers, Inc.

[5] Giroux H. A. (2001). Eğitimde kuram ve direniş [Theory and Resistance in Education] (S. Demiralp, trans.). Ankara: Dost Yayınevi.

[6] Field, J., C., \& Olafson, L., J. (1999). Understanding Resistance in Students at Risk. Canadian Journal of Education, 24(1), 70-75.

[7] Miles, R. D. (2007). Student resistance in the classroom. Chapin: YouthLigth, Inc

[8] Sever, D. (2012). Ilköğretim fen ve teknoloji dersinde araştırma temelli ögrenme yaklaşımının öğrenci dirençlerine etkisi [Effect of Inquiry-based Learning Approach on Student Resistance in a Science and Technology Course]. Unpublished doctoral dissertation, Anadolu University, Eskişehir, Turkey.

[9] Zhang, Q. (2011). Teacher Request Politeness: Effects on Student Positive Emotions and Compliance Intention. Human Communication. A Publication of the Pacific and Asian Communication Association, 14(4), 347-356. 10.06.2017

[10] Ruggeri-DiLello, T. A. (2015). The relationship between student misbehaviors and teacher self-efficacy. Unpublished master thesis. California State University, Fullerton, USA.

[11] Hastings, R. P., \& Bham, M. S. (2003). The relationship between student behaviour patterns and teacher burnout. School Psychology International, 24(1), 115-127. DOI: 10.1177/0143034303024001905

[12] Beşdok, D. (2007). Ortaöğretim öğretmenlerinin sınıf yönetiminde karşılaştıkları istenmeyen öğrenci davranışlarını önleyebilme yeterliklerinin değerlendirilmesi (Kayseri ili örneği) [The evolution of the secondary school teachers preventing ability of unexpected student behaviours (A case study in Kayseri)]. Unpublished mater thesis, Erciyes University, Kayseri, Turkey

[13] Kaşıkçı, S. (2011). Ögrencilerin matematik ögretmenlerini algilama şekilleri ile matematik kaygilari arasindaki ilişkilerin belirlenmesi. [The determination of relationships between secondary school students' perceptions of maths teachers and students' math anxiety. Unpublished mater thesis, Yakın Doğu University, Lefkoşa, Cyprus. 
[14] DeVellis, R. F. (2003). Scale development: Theory and applications. Thousand Oaks: Sage Publications.

[15] Erkuş. A. (2007). Ölçek Geliştirme ve Uyarlama Çalışmalarında Karşılaşılan Sorunlar [Problems in scale development and adaptation studies]. Türk Psikoloji Bülteni. 13(40). 17-25

[16] Tavşanc1l. E. (2002). Tutumların ölçülmesi ve SPSS ile veri analizi [Meassuremet the attitudes and data analysis with SPSS]. Ankara: Nobel Yayın Dağıtım

[17] Tezbaşaran, A. A. (1996). Likert tipi ölçek geliştirme kılavuzu [Guide for developing Likert type scale]. Ankara, Türk Psikoloji Derneği Yayınları

[18] Büyüköztürk. Ş. (2002). Faktör analizi: Temel kavramlar ve ölçek geliştirmede kullanımı [Factor analysis: Basic concepts and using to development scale]. Kuram ve Uygulamada Eğitim Yönetimi. 32, 470-483

[19] Cattel, R. B. (1978). The scientific use of factor analysis in behavioral and life sciences. New York: Plenum Press.

[20] Çokluk, Ö., Şekercioğlu, G., \& Büyüköztürk, Ş. (2010). Sosyal bilimler için çok değișkenli istatistik: SPSS ve LISREL uygulamalarl [Multivariate statistic for social sciences: SPSS and LISREL applications]. Ankara: Pegem Akademi

[21] Kalayc1, Ş. (Ed.). (2009). SPSS uygulamalı çok değişkenli istatistik teknikleri [Multivariate statistic techniques with SPSS applications]. Ankara: Asil Yayın dağıtım.

[22] Stevens, J. P. (2009). Applied Multivariate Statistics for the Social Sciences. New York: Routledge, Taylor \& Francis Group

[23] Büyüköztürk. Ş. (2005). Sosyal bilimler için veri analizi el kitabı [Data analysis manuel for social sciences]. Ankara: PegemA Yayıncilik.
[24] Cesur, O. \& Fer, S. (2007). Dil öğrenme stratejileri envanterinin geçerlik ve güvenirlik çalışması nedir? [What is the validity and reliability study of the strategy inventory of language learning?]. Yüzüncü Yıl Üniversitesi, Ĕ̈itim Fakültesi Dergisi. 4(2), 49-74.

[25] Schermelleh-Engel, K., \& Moosbrugger, H. (2003). Evaluating the fit of structural equation models: Tests of significance and descriptive goodness-of-fit measures. Methods of Psychological Research Online, 8(2), 23-74.

[26] Brown, T. A. (2006). Confirmatory factor analysis for applied research. New York: The Guilford Press.

[27] Schumacker, R. E. \& Lomax, R. G. (2004). A beginner's guide to structural equation modeling. London: Lawrence Erlbaum Associates, Publishers

[28] Evin-Gencel, İ. \& Saracaloğlu, A. S. (2013). An investigation of resistant behaviors of the teacher candidates toward the teaching certıficate courses. Cukurova University Faculty of Education Journal, 42(2), 87-98.

[29] Sheskin, D. J. (2000). Handbook of parametric and nonparametric statistical procedures. Second edition. Boca Raton: Chapman \& Hall/CRC

[30] Tabachnick, B. G. \& Fidell, L. S. (2001). Using multivariate statistics (4th Ed.). Boston: Allyn and Bacon.

[31] Gadermann A. M., Guhn M., \& Zumbo B., D. (2012). Estimating ordinal reliability for Likert-type and ordinal item response data: A conceptual, empirical, and practical guide. Practical Assessment, Research \& Evaluation, 17(3), 8-13.

[32] Tezbaşaran, A. A. (1997). Validity issues of a Likert type scale (a case study). Hacettepe Üniversitesi Eğitim Fakültesi Dergisi, 13, 41-45. 